\title{
PEMANFAATAN MEDIA GAMBAR DALAM MENINGKATKAN KETERAMPILAN MENULIS PARAGARAF DESKRIPSI SISWA KELAS II SDN 7 MONTONG BAAN
}

\author{
Lalu Syafi'i \\ SDN 7 Montong Baan \\ lalusyafii@gmail.com
}

\begin{abstract}
Abstrak: Penggunaan media pembelajaran yang sesuai dengan setiap materi pada berbagai mata pelajaran merupakan salah satu penentu keberhasilan pembelajaran. Media pembelajaran yang tersedia di lingkungan sekitar sangat banyak, namun terkadang tidak pernah dimanfaatkan oleh guru. Oleh karena itu, penelitian ini bertujuan untuk mengetahui efektivitas penggunaan media gambar dalam meningkatkan hasil belajar Bahasa Indonesia materi mendeskripsikan tumbuhan atau binatang di sekitar secara sederhana dengan bahasa tulis pada siswa kelas II SDN 7 Montong Baan. Metode yang digunakan dalam penelitian ini adalah observasi, angket/tes, dan wawancara. Hasil penelitian tindakan ini adalah menunjukkan bahwa hasil belajar Bahasa Indonesia materi mendeskripsikan tumbuhan atau binatang di sekitar secara sederhana dengan bahasa tulis pada siswa kelas II SDN 7 Montong Baan sebelum dilakukan tindakan sangat rendah. Hal ini dibuktikan dengan persentasi keberhasilannya adalah 19\%. Setelah dilakukan tindakan penggunaan media gambar hasil belajar tergolong sangat baik. Hal ini terbukti dengan persentasi keberhasilan pada variabel hasil belajar siswa pada siklus I yaitu 57,69\% dengan kriteria baik dan siklus II adalah $84,61 \%$ dengan kriteria sangat baik.
\end{abstract}

Kata kunci: metode diskusi, hasil belajar, materi menjelaskan proses Pemilu dan Pilkada

\section{A. PENDAHULUAN}

Keberhasilan dalam sebuah pembelajaran ditentukan oleh berbagai faktor baik yang terkait langsung dengan proses pembelajaran tersebut maupun yang tidak berkaitan secara langsung. Faktor-faktor yang dimaksud antara lain: (1) kemampuan dan keterampilan guru dalam menjalankan tugasnya sebagai seorang pendidik dan pengajar, (2) penggunaan metode dan teknik mengajar yang tepat oleh seorang guru, (3) penggunaan media pembelajaran yang sesuai dengan setiap materi pada berbagai mata pelajaran, (4) kesiapan mental dan fisik siswa yang akan menerima pembelajaran, (5) ketersediaan sarana dan prasarana pembelajaran yang memadai yang dapat dimanfaatkan siswa dalam menerima pelajaran, dan (6) dukungan penuh 
baik aspek materi maupun nonmateri dari semua pemangku kebijakan dalam dunia pendidikan.

Sebagai seorang guru yang ideal dan profesional, selayaknya semua faktor penentu keberhasilan dalam pembelajaran di atas harus dijadikan sebagai bahan pertimbangan dalam rangka peningkatan hasil pembelajaran. Pengkajian faktorfaktor tersebut tentunya tidak dapat dilakukan secara sekaligus, namun harus bertahap. Hal ini karena setiap faktor di atas memiliki banyak aspek yang perlu dikaji secara rinci. Secara teknis, semua faktor penentu keberhasilan pembelajaran di atas dapat dijadikan sebagai objek kajian dalam Penelitian Tindakan Kelas yang dilakukan oleh seorang guru baik yang berifat berkala mapun insidental.

Media pembelajaran yang dipilih guru merupakan salah satu cara meningkatkan hasil pembelajaran. Untuk mengefektifkan proses pembelajaran perlu digunakan media yang tepat. Kualitas pembelajaran akan meningkat jika guru mampu menciptakan kondisi belajar yang aktif. Untuk mengefektifkan pembelajaran, salah satu cara adalah dengan penggunaan media yang menarik sehingga dapat merangsang dan meningkatkan kemampuan belajar siswa.

Dalam penelitian ini, aspek yang akan dikaji adalah penggunaan media dalam peningkatan hasil belajar siswa. Penggunaan media pembelajaran selama ini diasumsikan oleh banyak guru dengan penggunaan sesuatu yang mahal dan sulit dicari. Asumsi ini jelas tidak benar karena hakikat penggunaan media pembelajaran adalah menciptakan suasana belajar menyenangkan, efektif, dan efisien. Media tersebut dapat diperoleh dari berbagai sumber dan tidak harus mahal. Penggunaan media pembelajaran diutamakan sesuatu yang dekat dengan siswa sehingga pembelajaran bermakna dapat diperoleh siswa. Dengan demikian, hasil pembelajaran pun diharapkan dapat meningkat dengan penggunaan media tersebut.

Media pembelajaran dalam penelitian ini adalah penggunaan media gambar berseri dalam upaya meningkatkan keterampilan menulis siswa. Sebagaimana penggunaan media pembelajaran lainnya, penggunaan media gambar berseri bertujuan untuk mengefektifkan pembelajaran sehingga dapat merangsang dan menciptakan kemampuan belajar siswa secara langsung terutama dalam hal menulis. Media gambar seri dapat digunakan untuk merangsang kemampuan menulis siswa karena siswa akan membuat tulisan terarah sesuai gambar seri yang digunakan. Artinya, gambar-gambar tersebut akan membantu siswa dalam memproduksi tulisan. Dengan demikian, siswa tidak dipaksa menulis berdasarkan imajinasi melainkan berdasarkan gambar yang ada.

Dalam lampiran Peraturan Menteri Pendidikan Nasional No. 23 Tahun 2006 tentang Standar Kompetensi Kelulusan (SKL) Kurikulum Tingkat Satuan Pendidikan (KTSP) Sekolah Dasar(SD) kelas II, terdapat Standar Kompetensi (SK) dan Kompetensi Dasar (KD). Salah satu Standar Kompetensi yang disebutkan dalam dokumen KTSP 
tersebut adalah (8. Menulis permulaan dengan mendeskripsikan benda di sekitar dan menyalin puisi anak). Standar Kompetensi ini kemudian diturunkan menjadi Kompetensi Dasar yaitu: 8.1 Mendeskripsikan tumbuhan atau binatang di sekitar secara sederhana dengan bahasa tulis dan 8.2 Menyalin puisi anak dengan huruf tegak bersambung yang rapi.

SK dan KD tersebut mengharuskan siswa kelas II SD untuk mampu mengungkapkan pikiran, perasaan, dan informasi dalam bentuk tulisan sederhana. Namun, kenyataan di lapangan menunjukkan bahwa sebagian besar siswa belum mampu memahami materi tersebut. Hal ini dilihat dari hasil evaluasi yaitu dari 26 orang siswa yang mengalami ketuntasan belajar baru mencapai 19\% sedangkan target ketuntasan belajar adalah $75 \%$.

Hasil belajar siswa yang belum memenuhi target ketuntasan belajar tersebut dipengaruhi oleh keterampilan dan kecermatan guru dalam memilih metode dan media pembelajaran yang tepat. Guru hanya berpatokan pada buku ajar yang ada dan tidak kreatif dalam menggunakan metode dan media yang sesuai dengan materi. Akibatnya keaktifan, partisipasi, dan motivasi belajar siswa menjadi rendah sehingga hasil belajar kurang baik.

Berdasarkan temuan tersebut, penulis berinisiatif menganalisis kembali penyebab rendahnya hasil belajar tersebut dengan memanfaatkan media belajar yang sesuai. Analisis mengenai rendahnya hasil belajar siswa kelas II Semester 2 di SDN 7 Montong Baan pada mata pelajaran Bahasa Indonesia dilaksanakan dengan penerapan media gambar seri akan mampu meningkatkan kemungkinan berpikir kritis, partisipasi, demokratis, mengembangkan sikap, motivasi, dan kemampuan menulis pada siswa. Dengan menerapkan media gambar seri diharapkan dapat meningkatkan keaktifan dan hasil belajar siswa SDN 7 Montong Baan.

\section{B. KERANGKA TEORI}

\section{Pengertian Belajar}

Belajar adalah suatu proses usaha yang dilakukan seseorang untuk memperoleh suatu perubahan tingkah laku yang baru secara keseluruhan, sebagai hasil pengalamannya sendiri dalam interaksi dengan lingkungannya Slameto (2003). Ahli lain berpendapat bahwa belajar adalah suatu proses yang komplek yang tejadi pada semua orang dan berlangsung seumur hidup, sejak ia masih bayi hingga ke liang lahat nanti Sardiman (2003). Dengan demikian, dapat disimpulkan bahwa belajar adalah suatu proses yang dilakukan seseorang untuk memperoleh suatu perubahan tingkah laku yang baru secara komplek sebagai hasil pengalamannya sendiri dalam interaksi dengan lingkungannya dan berlangsung seumur hidup. Dengan demikian belajar adalah sebuah proses perubahan di dalam kepribadian manusia dan perubahan 
tersebut ditampakkan dalam bentuk peningkatan kualitas dan kuantitas tingkah laku seperti peningkatan kecakapan, pengetahuan, sikap, kebiasaan, pemahaman, ketrampilan, daya pikir, dan kemampuan-kemampuan yang lain dalam kehidupan sehari-hari.

\section{Media Pembelajaran}

\section{a. Pengertian Media}

Menurut (Santoso S. Hamidjojo, 2011: diunduh dari http://nurmayantismi. blogspot.com) media adalah semua bentuk perantara yang dipakai orang menyebar ide, sehingga ide atau gagasan itu sampai pada penerima. Gagne (dalam Sadiman, 2009: 6) menyatakan bahwa media adalah berbagai jenis komponen dalam lingkungan siswa yang dapat merangsang untuk belajar. Sementara Bringgs (dalam Sadiman, 2009: 6) berpendapat bahwa media adalah segala alat fisik yang dapat menyajikan pesan serta merangsang siswa untuk belajar buku, film, kaset adalah contoh-contohnya. Selanjutnya Mc. Luhan (dalam Sadiman, 2009: 6) berpendapat bahwa media adalah sarana yang juga disebut channel, karena pada hakekatnya media memperluas atau memperpanjang kemampuan manusia untuk merasakan, mendengarkan, dan melihat dalam batas-batas jarak, ruang, dan waktu yang hampir tak terbatas lagi.

Azhar arsyad (2007: 3) memaparkan media apabila dipahami secara garis besar adalah manusia, materi atau kejadian yang membangun kondisi yang membuat siswa mampu memperoleh pengetahuan, kemampuan atau sikap. Dalam pengertian tersebut guru, buku teks dan lingkungan sekolah merupakan media dalam proses belajar mengajar. Sesuai dengan pendapat Azhar menurut Ratna (2011) yang diunduh dari alamat blog.umy.ac.id/.../PEMANFAATAN-MEDIA-DALAM-KOMUNIKA...) pada dunia pendidikan kita mengenal istilah "Media pendidikan". Media pendidikan sebagai alat bantu memiliki ciri-ciri:

1. Media pendidikan identik artinya dengan pengertian keparagaan yang berasal dari kata raga, suatu benda yang dapat diraba, dilihat, didengar, dan dapat diamati.

2. Tekanan utama terdapat pada benda atau hal-hal yang bisa dilihat dan didengar.

3. Media pendidikan digunakan dalam rangka hubungan (komunikasi) dalam pengajaran, antara guru dengan siswa.

4. Media pendidikan sebagai alat bantu belajar mengajar, baik diluar kelas.

5. Berdasarkan (3) dan (4), maka pada dasarnya media pendidikan merupakan suatu "perantara" (medium, media) dan digunakan dalam rangka pendidikan. 
6. Media pendidikan mengandung aspek; sebagai alat dan sebagai teknik, yang sangat erat pertaliannya dengan metode mengajar.

7. karena itu, sebagai tindakan operasional, dalam tulisan ini kita menggunakan pengertian "media pendidikan"

Batasan media pendidikan tersebut adalah alat, metode dan teknik yang digunakan dalam rangka mengaktifkan komunikasi serta interaksi antar guru dan siswa dalam proses pendidikan dan pengajaran disekolah. Pengertian media serta batasan-batasan yang dikemukakan oleh para ahli di atas, terdapat beberapa persamaan diantaranya, bahwa media adalah segala sesuatu yang dapat digunakan untuk menyalurkan pesan dari pengirim ke penerima sehingga dapat merangsang fikiran, perasaan, perhatian dan minat perhatian siswa sedemikian rupa sehingga proses belajar terjadi.

b. Jenis-Jenis Media

Pengelompokkan berbagai jenis media apabila dilihat dari segi perkembangan teknologi oleh Seels dan Glassgow dalam Azhar Arsyad (2007: 33) di bagi dalam dua kategori yaitu media tradisional dan media teknologi mutakhir.

1. Media tradisional

Media tradisional dapat berupa (a) visual diam yang diproyeksikan, sebagai contoh overhead, slides, filmstrips, (b) visual yang tak diproyeksikan, sebagai contoh gambar, foto, chart, grafik, diagram, dan pameran foto, (c) audio, sebagai contoh rekaman, piringan, pita kaset, ree; dan cartridge,

(d) visual dinamis yang diproyeksikan, sebagai contoh film, televisi, dan video, (e) cetak, sebagai contoh buku, workbook, majalah dan lembaran lepas, (f) permainan, sebagai contoh teka-teki, simulasi, dan permainan papan.

2. Media teknologi mutakhir

Media teknologi mutakhir yang terdiri dari media berbasis telekomunikasi contohnya teleconferen dan media berbasis mikroprosesor contohnya permainan computer, compat disc.

3. Media Gambar

Menurut (Sanjaya, 2012: diunduh dari www.sarjanaku.com) media gambar adalah media yang dipergunakan untuk memvisualisasikan atau menyalurkan pesan dari sumber ke penerima (siswa). Pesan yang akan disampaikan dituangkan ke dalam komunikasi visual, di samping itu media gambar berfungsi pula untuk menarik perhatian, memperjelas 
sajian ide, mengilustrasikan atau menghiasi fakta yang mungkin akan cepat dilupakan atau diabaikan bila tidak digrafiskan.

Smaldino (dalam Anitah, 2009: 14) menyatakan bahwa melalui gambar dapat diterjemahkan ide-ide abstrak ke dalam bentuk yang lebih realistik. Edgar Dale (dalam Anitah, 2009: 14) menyatakan bahwa gambar dapat mengalihkan pengalaman belajar dari taraf belajar dengan lambang katakata ke taraf yang lebih kongkrit. Semua gambar mempunyai arti, uraian dan tafsiran sendiri. Media gambar merupakan alat bantú proses belajar mengajar, karena melalui gambar siswa dapat melihat dengan jelas sesuatu yang sedang dibicarakan atau didiskusikan di dalam kelas.

4. Fungsi Media Gambar

Robertus Angkowo dan A.Kokasih (2007: 27) menyebutkan bahwa, dalam proses pembelajaran, ada dua unsur yang sangat penting yakni metode dan media pembelajaran. Pemilihan metode tertentu akan mempengaruhi jenis media yang sesuai dengan metode yang digunakan. Secara umum fungsi media gambar dapat diringkas sebagi berikut: (a) sebagai alat bantu pembelajaran, (b) dapat memperjelas pesan agar tidak terlalu bersifat verbal, (c) memanfaatkan media secara tepat dan bervariasi akan dapat mengurangi sifat sikap pasif siswa, (d) dapat membangkitkan keinginan dan minat baru, membangkitkan motivasi dan rangsangan kegiatan belajar, dan bahkan membawa pengaruh psikologis terhadap siswa, (e) berguna untuk membangkitkan gairah belajar, memungkinkan siswa untuk belajar mandiri sesuai dengan minat dan kemampuan siswa. (f) dapat meningkatkan pengetahuan, memperluas pengetahuan, serta memberikan fleksibelitas dalam menyampaikan pesan. (g) sebagai alat komunikasi, sebagai sarana pemecahan masalah dan sebagai sarana pengembangan diri.

Berdasarkan fungsi media secara umum tersebut di atas, maka dapat dirumuskan bahwa fungsi media gambar dalam pembelajaran adalah untuk membangkitkan motivasi belajar siswa dan sebagai alat komunikasi dalam menyampaikan pesan (materi pembelajaran) yang lebih kongkrit pada siswa, sehingga lebih mudah dipahami.

\section{METODE PENELITIAN}

\section{Setting Penelitian}

Penelitian ini dilakukan di SDN 7 Montong Baan Kecamatan Sikur Kabupaten Lombok Timur. Adapun subjek penelitian ini adalah siswa kelas II. SDN 7 Montong Baan. 


\section{Pengumpulan Data}

Pengumpulan data dalam penelitian ini menggunakan teknik tes tertulis dan lembar observasi kegiatan belajar dan pembelajaran yang dilakukan siswa. Teknik tes yaitu tes formatif untuk mengetahui hasil belajar siswa setelah dilakukan tindakan, sedangkan tes observasi dilakukan untuk mengamati aktifitas siswa dan guru selama dilakukan tindakan.

\section{Analisis Data}

Penelitian ini bersifat kuantatif deskriptif karena memaparkan data yang diperoleh melalui observasi dan tes hasil belajar menggunakan statistik deskriptif, yaitu statistik yang berfungsi untuk menggambarkan tentang suatu keadaan.

\section{Hipotesis Penelitian}

Sebagaimana telah dijelaskan di atas bahwa keberhasilan dalam proses pembelajaran salah satunya ditentukan oleh penggunaan media pembelajaran. Penggunaan media pembelajaran yang sesuai dengan materi pembelajaran diyakini dapat meningkatkan hasi pembelajaran. Dengan demikian, dalam penelitian ini dapat dirumuskan hipotesis bahwa penggunaan media gambar dapat meningkatkan hasil belajar dalam menulis paragraf deskripsi. Kategorisasi hasil belajar siswa dapat dilihat pada tabel kategori hasil belajar berikut ini:

Tabel 1.

Kategori Hasil Belajar

\begin{tabular}{|c|c|}
\hline Nilai & Kategori \\
\hline $80-100$ & Sangat Baik \\
\hline $70-79$ & Baik \\
\hline $60-69$ & Cukup \\
\hline $50-59$ & Kurang \\
\hline $0-49$ & Sangat Kurang \\
\hline (Muhibiansyah, 1995) \\
\hline
\end{tabular}

Tabel 2.

Penilaian secara kuantitas dan kualitas tentang nilai rata-rata siswa

\begin{tabular}{|c|c|c|}
\hline Skala Nilai & \multicolumn{2}{|c|}{ Nilai Kualitas } \\
\hline (Nilai Kuantitas) & Huruf & Kriteria \\
\hline $80 \%<\mathrm{X} \leq 100 \%=5$ & $\mathrm{~A}$ & Sangat baik \\
\hline $60 \%<\mathrm{X} \leq 80 \%=4$ & $\mathrm{~B}$ & Baik \\
\hline
\end{tabular}




\begin{tabular}{|c|c|c|}
\hline $40 \%<X \leq 60 \%=3$ & $C$ & Cukup \\
\hline $20 \%<X \leq 40 \%=2$ & $D$ & Kurang \\
\hline $0 \%<X \leq 20 \%=1$ & E & Sangat kurang \\
\hline
\end{tabular}

Sumber : Arikunto (2005)

Indikator keberhasilan dalam penelitian ini adalah jika pembelajaran yang berlangsung dapat meningkatkan hasil belajar siswa. Proses pembelajaran dinyatakan berhasil apabila:

a. Nilai hasil belajarsiswa mencapai minimal 65, dengan prosentasi ketuntasan belajar $75 \%$.

b. Tingkat keaktifan siswa meningkat dari sebelum dan sesudah melakukan tindakan dengan prosentasi keberhasilan minimal $75 \%$.

\section{Pembahasan}

Observasi dalam penelitian ini dilakukan selama dua pertemuan yang masingmasing pertemuan diisi dengan beberapa rangkaian atau proses pembelajaran yang disebut siklus. Berdasarkan data hasil pengamatan aktivitas siswa dalam proses pembelajaran menulis paragraf deskripsi menggunakan media gambar berseri pada siklus I dapat digambarkan pada tabel sebagai berikut:

1. Observasi Aktivitas Siswa

Aktivitas siswa pada siklus satu dapat digambarkan pada tabel di bawah ini.

Tabel 3.

Hasil Observasi Klasikal Aktivitas Siswa Siklus I

\begin{tabular}{|c|c|c|c|c|c|c|c|}
\hline \multirow{2}{*}{ No } & Indikator & \multicolumn{3}{|c|}{ Perolehan Skor } & Jumlah & Rata- \\
Skor & Rata \\
\cline { 3 - 7 } 1 & Antusiasme mengikuti pembelajaran & 7 & 8 & 5 & 6 & 62 & 2,4 \\
\hline 2 & Menuangkan ide/ gagasan & 5 & 8 & 8 & 5 & 65 & 2,5 \\
\hline 3 & Memahami konsep materi & 2 & 6 & 12 & 6 & 70 & 2,7 \\
\hline 4 & $\begin{array}{c}\text { Mengemukakan kesalahan dalam } \\
\text { penulisan }\end{array}$ & 5 & 5 & 11 & 5 & 68 & 2,6 \\
\hline 5 & Berdiskusi dengan teman & 3 & 10 & 7 & 6 & 68 & 2,6 \\
\hline
\end{tabular}




\begin{tabular}{|l|c|c|c|c|c|c|c|}
\hline 6 & $\begin{array}{c}\text { Melakukan perbaikan dan me- } \\
\text { masang karya }\end{array}$ & 5 & 8 & 8 & 5 & 65 & 2,5 \\
\hline Jumlah & \multicolumn{2}{|c|}{398} \\
\hline Rata-rata & \multicolumn{2}{|c|}{15,3} \\
\hline
\end{tabular}

Observasi aktivitas siswa selama proses pembelajaran menulis karangan sederhana berbahasa Indonesia dengan media gambar seri diperoleh rata-rata skor 15,3 dengan kategori baik. Berikut penjelasannya:

1. Indikator antusias mengikuti pembelajaran diperoleh hasil 7 siswa memperoleh skor satu, 8 siswa memperoleh skor dua, 5 siswa memperoleh skor tiga dan 6 siswa memperoleh skor empat. Rata-rata skor yang diperoleh adalah 2,4 .

2. Indikator dapat menuangkan ide/gagasan diperoleh hasil 5 siswa memperoleh skor satu, 8 siswa memperoleh skor dua, 8 siswa memperoleh skor tiga dan 5 siswa memperoleh skor empat. Rata-rata skor yang diperoleh adalah 2,5 .

3. Indikator memahami konsep materi diperoleh hasil 2 siswa memperoleh skor satu, 6 siswa memperoleh skor dua, 12 siswa memperoleh skor tiga dan 6 siswa memperoleh skor empat. Rata-rata skor yang diperoleh adalah 2,7 .

4. Indikator dapat mengemukakan kesalahan dalam penulisan diperoleh hasil 5 siswa memperoleh skor satu, 5 siswa memperoleh skor dua, 11 siswa memperoleh skor tiga dan 5 siswa memperoleh skor empat. Ratarata skor yang diperoleh adalah 2,6.

5. Indikatordapatberdiskusidengantemandiperolehhasil3 siswamemperoleh skor satu, 10 siswa memperoleh skor dua, 7 siswa memperoleh skor tiga dan 6 siswa memperoleh skor empat. Rata-rata skor yang diperoleh adalah 2,6 .

6. Indikator dapat melakukan perbaikan dan memasang karya diperoleh hasil 5 siswa memperoleh skor satu, 8 siswa memperoleh skor dua, 8 siswa memperoleh skor tiga dan 5 siswa memperoleh skor empat. Rata-rata skor yang diperoleh adalah 2,5.

\section{a. Paparan Hasil Belajar Siswa Siklus I}

Keterampilan menulis karangan sederhana berbahasa Indonesia dengan media gambar berseri pada siswa kelas II SDN 7 Montong Baan pada siklus I belum menunjukkan hasil yang maksimal. Hasil observasi pada keterampilan menulis 
karangan sederhana berbahasa Indonesia dengan media gambar berseri dapat dilihat pada tabel di bawah ini:

Tabel 4 Skor Keterampilan Siswa Menulis Paragraf Deskripsi pada Siklus I

\begin{tabular}{|c|c|c|c|c|c|c|c|}
\hline \multirow{2}{*}{ No } & \multirow{2}{*}{ Aspek } & \multicolumn{4}{|c|}{ Perolehan Skor } & \multirow{2}{*}{$\begin{array}{l}\text { Jum- } \\
\text { lah }\end{array}$} & \multirow{2}{*}{$\begin{array}{l}\text { Rata- } \\
\text { Rata }\end{array}$} \\
\hline & & 1 & 2 & 3 & 4 & & \\
\hline 1 & $\begin{array}{l}\text { Potongan gambar tersusun secara runtut } \\
\text { dan logis }\end{array}$ & 4 & 4 & 15 & 3 & 69 & 2,6 \\
\hline 2 & $\begin{array}{c}\text { Pemilihan kalimat utama sesuai dengan } \\
\text { gambar }\end{array}$ & 2 & 12 & 11 & 1 & 63 & 2,4 \\
\hline 3 & $\begin{array}{l}\text { Pengembangan kalimat utama menjadi } \\
\text { paragraf logis dan sederhana }\end{array}$ & 6 & 7 & 12 & 1 & 48 & 1,8 \\
\hline 4 & Ketepatan penulisan ejaan dan tanda baca & 3 & 3 & 13 & 7 & 76 & 2,9 \\
\hline 5 & Kesesuaian judul dan isi & 4 & 5 & 7 & 10 & 75 & 2,9 \\
\hline 6 & Kerapihan tulisan & 3 & 4 & 12 & 7 & 75 & 2,9 \\
\hline \multicolumn{6}{|c|}{ Jumlah } & \multicolumn{2}{|c|}{406} \\
\hline \multicolumn{6}{|c|}{ Rata-rata } & \multicolumn{2}{|c|}{15,5} \\
\hline \multicolumn{6}{|c|}{ Kategori } & \multicolumn{2}{|c|}{ Tuntas } \\
\hline
\end{tabular}

Berdasarkan analisis keterampilan siswa menulis karangan sederhana dapat dijelaskan sebagai berikut:

1. Jumlah skor yang didapat pada aspek potongan gambar tersusun secara urut dan logis adalah 69 dengan rata-rata skor 2,6.

2. Jumlah skor yang didapat pada aspek pemilihan kalimat utama sesuai dengan gambar adalah 63 dengan rata-rata skor 2,4.

3. Jumlah skor yang didapat pada aspek Pengembangan kalimat utama menjadi paragraf logis dan sederhana adalah 48 dengan rata-rata skor 1,8.

4. Jumlah skor yang didapat pada aspek ketepatan penulisan ejaan dan tanda baca adalah 76 dengan rata-rata skor 2,9 .

5. Jumlah skor yang didapat pada aspek kesesuaian judul dan isi adalah 75 dengan rata-rata skor 2,9 .

6. Jumlah skor yang didapat pada aspek kerapihan tulisan adalah 75 dengan ratarata skor 2,9 .

7. Jumlah skor yang diperoleh secara keseluruhan untuk semua indikator pada siklus I adalah 406 dengan rata-rata skor 15,5 termasuk kualifikasi tuntas. Hasil ini perlu ditingkatkan pada siklus II. 
Adapun hasil belajar siswa menulis karangan sederhana berbahasa Indonesia dengan media gambar berseri adalah sebagai berikut:

Tabel 5 .

Hasil Belajar Siswa Siklus I

\begin{tabular}{|c|c|c|c|c|}
\hline Interval Nilai & $\begin{array}{c}\text { Frekue- } \\
\text { nsi }\end{array}$ & $\begin{array}{c}\text { Frekuensi } \\
\text { Relatif }\end{array}$ & KKM & Kualifikasi \\
\hline $80-100$ & 3 & $11 \%$ & & Tuntas \\
\hline $65-79$ & 12 & $46 \%$ & & Tuntas \\
\hline $56-64$ & 5 & $19 \%$ & & Tidak Tuntas \\
\hline $40-55$ & 6 & $23 \%$ & \multirow{3}{*}{65} & \\
\cline { 2 - 3 } & 26 & & \\
\hline Jumlah & 68,4 & & \\
\hline Rata-rata & 15 & $57 \%$ & & \\
\hline Siswa yang tuntas & 11 & $43 \%$ & & \\
\hline Siswa yang belum tuntas & & & \\
\hline
\end{tabular}

Berdasarkan analisis hasil belajar pada siklus I ketuntasan belajar klasikal baru dicapai oleh 15 orang siswa atau sebesar 57\% Untuk ketidaktuntasan belajar sebesar 43\%. Dengan demikian, untuk memperbaiki hasil belajar perlu dilakukan pembelajaran dengan menggunakan media gambar pada siklus II.

b. Paparan Hasil Belajar Siswa pada Siklus II

Keterampilan menulis paragraf deskripsi dengan media gambar berseri pada siswa kelas II SDN 7 Montong Baan pada siklus II sudah memenuhi indikator keberhasilan. Hasil observasi pada keterampilan menulis paragraf deskripsi dengan media gambar berseri dapat dilihat pada tabel di bawah ini:

Tabel 6.

Skor Keterampilan Siswa Menulis Paragraf Deskripsi dengan Media gambar pada Siklus II

\begin{tabular}{|c|c|c|c|c|c|c|c|}
\hline No & Aspek & \multicolumn{3}{|c|}{ Perolehan Skor } & Jumlah & $\begin{array}{c}\text { Rata- } \\
\text { Rata }\end{array}$ \\
\hline 1 & $\begin{array}{c}\text { Potongan gambar tersusun secara run- } \\
\text { tut dan logis }\end{array}$ & 4 & 2 & 9 & 9 & 71 & 3,0 \\
\hline 2 & $\begin{array}{c}\text { Pemilihan kalimat utama sesuai dengan } \\
\text { gambar }\end{array}$ & 2 & 4 & 5 & 15 & 83 & 3,4 \\
\hline 3 & $\begin{array}{c}\text { Pengembangan kalimat utama menjadi } \\
\text { paragraf logis dan sederhana }\end{array}$ & 1 & 4 & 10 & 11 & 76 & 3,2 \\
\hline 4 & $\begin{array}{c}\text { Ketepatan penulisan ejaan dan tanda } \\
\text { baca }\end{array}$ & 1 & 3 & 11 & 11 & 76 & 3,2 \\
\hline 5 & Kesesuaian judul dan isi & 1 & 1 & 5 & 19 & 91 & 3,1 \\
\hline
\end{tabular}




\begin{tabular}{|c|c|c|c|c|c|c|c|}
\hline 6 & Kerapihan tulisan & 1 & 2 & 9 & 14 & 82 & 3,4 \\
\hline \multicolumn{6}{|c|}{ Jumlah } & \multicolumn{2}{|c|}{479} \\
\hline \multicolumn{6}{|c|}{ Rata-rata } & \multicolumn{2}{|c|}{19,9} \\
\hline \multicolumn{6}{|c|}{ Kategori } & \multicolumn{2}{|c|}{ Tuntas } \\
\hline
\end{tabular}

Berdasarkan analisis keterampilan siswa menulis paragraf deskripsi dengan media gambar dapat dijelaskan sebagai berikut:

1. Jumlah skor yang didapat pada aspek potongan gambar tersusun secara urut dan logis adalah 71 dengan rata-rata skor 3,0.

2. Jumlah skor yang didapat pada aspek pemilihan kalimat utama sesuai dengan gambar adalah 83 dengan rata-rata skor 3,4.

3. Jumlah skor yang didapat pada aspek Pengembangan kalimat utama menjadi paragraf logis dan sederhana adalah 76 dengan rata-rata skor 3,2.

4. Jumlah skor yang didapat pada aspek ketepatan penulisan ejaan dan tanda baca adalah 76 dengan rata-rata skor 3,2.

5. Jumlah skor yang didapat pada aspek kesesuaian judul dan isi adalah 91 dengan rata-rata skor 3,1 .

6. Jumlah skor yang didapat pada aspek kerapihan tulisan adalah 82 dengan rata-rata skor 3,4.

7. Jumlah skor yang diperoleh secara keseluruhan untuk semua indikator pada siklus II adalah 478 dengan rata-rata skor 19,9 termasuk kualifikasi tuntas.

Hasil observasi pada keterampilan menulis paragraf deskripsi dengan media gambar berseri dapat dilihat pada tabel di bawah ini:

Tabel 7.

Hasil Belajar Siswa Siklus II

\begin{tabular}{|c|c|c|c|c|}
\hline Interval Nilai & Frekuensi & $\begin{array}{c}\text { Frekuensi } \\
\text { Relatif }\end{array}$ & KKM & Kualifikasi \\
\hline $80-100$ & 16 & $61 \%$ & & Tuntas \\
\hline $65-79$ & 6 & $23 \%$ & & Tuntas \\
\hline $56-64$ & 2 & $8 \%$ & \multirow{4}{*}{65} & Tidak Tuntas \\
\cline { 2 - 3 } \cline { 3 - 3 } TidakTuntas \\
\hline Jumlah & 2 & $8 \%$ & & \\
\hline Siswa yang tuntas & 26 & $84 \%$ & & \\
\hline Siswa yang belum tuntas & 4 & $16 \%$ & & \\
\hline
\end{tabular}


Berdasarkan analisis hasil belajar pada siklus II ketuntasan belajar klasikal sebesar $84 \%$ Untuk ketidaktuntasan belajar sebesar 16\%.

Dengan demikian pada siklus II hasil belajar siswa sudah mencapai indikator yang diharapkan, dari tabel tersebut pengambilan data melalui tes tertulis sudah menunjukkan adanya peningkatan dan memenuhi indikator dari hasil menulis paragraf deskripsi dengan media gambar pada siswa kelas II SDN 7 Montong Baan..

\section{PENUTUP}

Berdasarkan hasil peneltian dan pembahasan pada bab sebelumnya, penelitian ini dapat disimpulkan sebagai berikut:

1. Hasil belajar Bahasa Indonesia materi keterampilan menulis paragraf deskripsi dengan media gambar menggunakan pilihan kata dan kalimat yang tepat dengan memperhatikan penggunaan ejaan, huruf kapital, dan tanda titik pada siswa kelas II SDN 7 Montong Baan sebelum dilakukan tindakan sangat rendah. Hal ini dibuktikan dengan persentasi keberhasilannya adalah $19 \%$. Setelah dilakukan tindakan penggunaan media gambar beseri hasil belajar tergolong sangat baik. Hal ini terbukti dengan persentasi keberhasilan pada variabel hasil belajar siswa pada siklus I yaitu $57,69 \%$ dengan kriteria baik dan siklus II adalah $84,61 \%$ dengan kriteria sangat baik.

2. Pelaksanaan pembelajaran keterampilan menulis paragraf deskripsi dengan media gambar menggunakan pilihan kata dan kalimat yang tepat dengan memperhatikan penggunaan ejaan, huruf kapital, dan tanda titik pada siswa kelas II SDN 7 Montong Baan tergolong baik. Hal ini terbukti dengan persentasi keberhasilan pada variabel keaktifan siswa pada siklus 1 rerata 15,3 dengan kriteria baik dan siklus 2 rerata 20,03 dengan kriteria sangat baik.

3. Peningkatan hasil belajar Bahasa Indonesia materi keterampilan menulis paragraf deskripsi dengan media gambar menggunakan pilihan kata dan kalimat yang tepat dengan memperhatikan penggunaan ejaan, huruf kapital, dan tanda titik pada siswa kelas II SDN 7 Montong Baan cukup signifikan. Hal ini terbukti dengan tingkat pencapaian hasil belajar siswa pada siklus pertama dan siklus kedua meningkat yaitu dari $57,69 \%$ menjadi $84,61 \%$. 


\section{DAFTAR PUSTAKA}

Arikunto, 2005. Dasar-Dasar Evaluasi Pendidikan. Jakarta: Bumi Aksara Pembelajaran yang Efektif/ 22-01-2008.

Depdiknas, 2005. Model-model Pembelajaran yang Efektif. http://ktsp.diknas.go./ download/ktsp_smk/14.ppt\#7 Model-model Pembelajaran yang Efektif/ 2201-2008.

Djamarah, 2002. Prestasi Belajar dan Kompetensi Guru. Surabaya : Usaha Nasional.

Ibrahim, 2003. Pembelajaran Kooperatif. Surabaya: University Press.

Muhibiansyah, 1995. Penilaian Hasil Belajar Mengajar. Jakarta : Kanisius.

Pramudjono, 2003. Statistika Dasar. FKIP Samarinda: UNMUL.

Riyanto, 2001. Paradigma Pembelajaran. Surabaya: Unesa University Press.

Sardiman (2003. Interaksi dan Motivasi Belajar. Jakarta : Raja Grafindo.

Slameto , 2003. .Belajar dan Pembelajaran. Jakarta : Rineka Cipta.

1989. Penilaian Hasil Belajar. Bandung : Remaja Rosdakarya.

Sudjana, 2002. Dasar-Dasar Proses Belajar Mengajar. Bandung: Sinar Baru Algesindo. 